\title{
Ferruginous bodies and pulmonary fibrosis in dead low to moderately exposed asbestos cement workers: histological examination
}

\author{
L G JOHANSSON, ${ }^{1}$ MARIA P ALBIN, ${ }^{2}$ KRISTINA M JAKOBSSON, ${ }^{2}$ \\ H E C WELINDER, ${ }^{2}$ P J RANSTAM ${ }^{3}$ ROBYN G ATTEWELL ${ }^{2}$
}

From the Departments of Pathology, ${ }^{1}$ Occupational Medicine, ${ }^{2}$ and the Regional Cancer Register, ${ }^{3}$ University Hospital, S-221 85 Lund, Sweden

ABSTRACT Histological slides from the lungs of 89 dead asbestos cement workers have been exam-io ined with respect to ferruginous bodies and fibrosis. The results have been compared with individu-y ally matched controls with no known exposure to asbestos, and related to asbestos exposure, expressed as duration of exposure and cumulative asbestos dose, and smoking habits. The asbestos? cement workers studied had been employed for on average 15 years, with a mean cumulative dose of 26 fibre-years per $\mathrm{ml}(\mathrm{f}-\mathrm{y} / \mathrm{ml})$. Clear dose-response relations between exposure (duration of exposure and cumulative asbestos dose) and level of ferruginous bodies were found. An association命 was evident already at a low cumulative dose (1-10 f-y/ml). Fibrosis was more common and more $\vec{\bullet}$ pronounced among the exposed workers than among controls. An association between ferruginous bodies and fibrosis was also found. Among the controls, but not among exposed workers, there was an association between smoking history and fibrosis.

In the first decades of the twentieth century it became evident that exposure to asbestos fibres could lead to diffuse pulmonary fibrosis, a condition termed asbestosis. ${ }^{2}$ Dose-response relations between exposure in different industrial settings and response expressed as clinical signs of interstitial lung disease, radiological changes, physiological changes, or mortality in pneumoconiosis have been established. ${ }^{3}$ Information on this subject is, however, still insufficient, especially in the area of low exposure. The adverse effects of asbestos seen today reflect exposure decades earlier with dust concentrations usually far exceeding the levels of interest in current TLV discussions.

Some authors have argued that findings from other branches of the asbestos industry cannot be applied to the asbestos cement industry as the fibres are covered with calcium particles during processing. ${ }^{4}$ As the asbestos cement industry is now the main consumer of the world asbestos production and is still expanding, adverse effects of exposure to asbestos cement are of considerable interest.

We have investigated the relations between asbestos dose and histological lung fibrosis and ferruginous

Accepted 1 September 1986 bodies in low to moderately exposed asbestos cement workers. Smoking habits have also been studied, as smoking in itself may cause lung fibrosis ${ }^{5}$ and might have a confounding effect on the fibrosis caused by asbestos. $^{6-10}$

\section{Material and methods}

THE FACTORY

An asbestos cement plant in the south of Sweden produced sheets, shingles, ventilation pipes, and various hand moulded details between 1907 and 1977. The asbesos handled was mainly chrysotile $(>90 \%)$. Cro-음 cidolite was used before 1966 in small amounts, usu- $\frac{D}{2}$ ally $<1 \%$ of the total asbestos used and never exceeding 3-4\%. Amosite might have been used in small amounts in the 1950s. All types of asbestos were milled before mixing. The Portland cement used had a low silica content (below $0 \cdot 1 \%$ ). There was littlec change in formula or process over the history of the plant, except for changing from dry to wet milling ine 1952. Systematic efforts to reduce the dust concen- $\mathbb{D}$ trations started in the late 1960s.

The work force reached a maximum in the mid 1960s with 450 employees. The turnover was low as the plant was located in a small community. 


\section{EXPOSURE}

Dust measurements are available for the period 1956-77. Before 1969 only impinger or gravimetric determinations exist. The membrane filter method was introduced in 1969 and fully replaced the impinger method from 1971 together with a gravimetric method for determination of total dust. Some data exist from simultaneous samplings with the different methods. Extensive sampling was performed after 1975. The average dust exposure for different jobs and periods has been estimated in fibres per $\mathrm{ml}(\mathrm{f} / \mathrm{ml})$ from data on dust concentrations, production, and dust control. The duration of specific tasks during the workday has been taken into account. Only millers, mixers, and workers performing sawing and polishing operations were continually exposed to more than $2 \mathrm{f} / \mathrm{ml}$ (table 1). Occasional exposure to high dust concentrations occurred during unloading and storing of asbestos bags; this has not been taken into account.

Conversion factors from million particles per cubic foot (mppcf) to $\mathrm{f} / \mathrm{ml}$ are based on simultaneous samplings in this plant and in another asbestos cement factory.

\section{EXPOSED WORKERS}

In the total cohort of 3144 male and female blue collar workers employed for more than three months between 1907 and 1977, starting employment before 1 January 1976, there were 707 deaths until 1980 when this study started. In 396 cases a necropsy had been performed. For 89 of these the criteria for inclusion in this study were fulfilled - that is, a necropsy performed at the Department of Pathology, University Hospital, or the Institute for Forensic Medicine, Lund, and the availability of at least two blocks of lung tissue not containing tumours. The mean age of the 84 men and five women at death was 66 (range 35-91). On average 3.7 blocks of lung tissue were preserved.

\section{CONTROL POPULATION}

For each case, the next person of the same sex and age at death (within five years) in the necropsy files of the University Hospital of Lund was chosen as a control. Those who might have been exposed to agents causing pneumoconiosis (as from information about occupation in the medical record) were rejected and another control was chosen. For $\mathbf{4 6}$ controls the main occupation was either not known or was specified as labourer. Of the remainder, 21 were manual workers, including five construction workers, and 22 were white collar workers. Their mean age at death was 67 (37-93). On average 3.4 blocks of lung tissue were preserved.

Table 1 Average airborne dust concentrations (fibres and total dust) for different job assignments and periods. Measured and estimated concentrations and sampling time is given

\begin{tabular}{|c|c|c|c|c|c|}
\hline \multirow[b]{2}{*}{ Period and type of measurement } & \multicolumn{5}{|c|}{ Job assignment } \\
\hline & Milling & Mixing & Forming machine & Sawing & Grinding \\
\hline $\begin{array}{l}\text { 1956: } \\
\text { Gravimetric method* }\end{array}$ & & & & & \\
\hline Total dust $\left(\mathrm{mg} / \mathrm{m}^{3}\right)$ & $6 \cdot 7$ & $5 \cdot 5$ & - & $2 \cdot 8$ & 0.7 \\
\hline $\begin{array}{l}\text { Impinger: } \\
\text { Particles (mppcf) } \\
\text { Sampling time (h) } \\
\text { Fibres } \dagger\end{array}$ & $\begin{array}{l}15 \\
0 \cdot 8 \\
6 \cdot 0\end{array}$ & $\begin{array}{r}29 \\
0 \cdot 8 \\
3 \cdot 0\end{array}$ & $\begin{array}{l}8 \\
0 \cdot 8 \\
1 \cdot 5\end{array}$ & $\begin{array}{l}24 \\
1 \cdot 2 \\
4 \cdot 0\end{array}$ & $\begin{array}{r}47 \\
0 \cdot 4 \\
6 \cdot 3\end{array}$ \\
\hline $\begin{array}{l}\text { 1965: } \\
\text { Impinger: }\end{array}$ & & & & & \\
\hline $\begin{array}{l}\text { Particles (mppcf) } \\
\text { Sampling time (h) } \\
\text { Fibres } \dagger\end{array}$ & $\begin{array}{r}21 \\
0 \cdot 3 \\
5 \cdot 0\end{array}$ & $\begin{array}{l}4 \\
0 \cdot 03 \\
2 \cdot 0\end{array}$ & $\begin{array}{l}11 \\
0 \cdot 2 \\
1 \cdot 2\end{array}$ & $\begin{array}{l}16 \\
0 \cdot 1 \\
2 \cdot 8\end{array}$ & $\begin{array}{l}45 \\
0 \cdot 1 \\
5 \cdot 5\end{array}$ \\
\hline $\begin{array}{l}\text { 1969: } \\
\text { Impinger: }\end{array}$ & & & & & \\
\hline $\begin{array}{l}\text { Total dust (mg/m } \mathrm{m}^{3} \text { ) } \\
\text { Particles (mppcf) } \\
\text { Sampling time (h) }\end{array}$ & $\begin{array}{l}3.3 \\
0.4\end{array}$ & $\begin{array}{l}-3 \\
0 \cdot 3\end{array}$ & $\begin{array}{l}0.5 \\
2 \\
0 \cdot 8\end{array}$ & $\begin{array}{l}2 \cdot 5 \\
9 \\
1 \cdot 2\end{array}$ & $\begin{array}{l}9 \\
0.9\end{array}$ \\
\hline $\begin{array}{l}\text { Membrane filter: } \\
\text { Fibres (f/ml) } \\
\text { Sampling time (h) }\end{array}$ & 26 & $\begin{array}{l}0 \cdot 3 \\
2 \cdot 2\end{array}$ & $\begin{array}{l}0 \cdot 3 \\
7 \cdot 1\end{array}$ & $\begin{array}{l}1 \cdot 7 \\
0 \cdot 5\end{array}$ & - \\
\hline $\begin{array}{l}\text { 1975: } \\
\text { Membrane filter: } \\
\text { Total dust }\left(\mathrm{mg} / \mathrm{m}^{3}\right) \\
\text { Fibres (f/ml) } \\
\text { Sampling time (h) }\end{array}$ & $\begin{array}{l}4 \cdot 5 \\
1 \cdot 7 \\
29\end{array}$ & $\begin{array}{l}5 \cdot 0 \\
1 \cdot 3 \\
13\end{array}$ & $\begin{array}{c}2 \cdot 3 \\
0.9 \\
12\end{array}$ & $\begin{array}{l}4 \cdot 5 \\
1 \cdot 2 \\
28\end{array}$ & $\begin{array}{c}4 \cdot 0 \\
1 \cdot 5 \\
10\end{array}$ \\
\hline
\end{tabular}

* Stationary sampling.

†Estimated value. 


\section{SMOKING HABITS}

A postal inquiry to the relatives was used to obtain information on smoking habits. The accumulated consumption of tobacco was calculated as pack-years (years smoking $\times$ daily consumption in terms of packs of cigarettes). Pipe tobacco and cigars were included (converting $1 \mathrm{~g}$ of tobacco to one cigarette). The average tobacco consumption among 81 exposed workers whose smoking habits could be established was 22 (0-116) pack-years; 19 were lifelong nonsmokers. Among the 66 controls with known smoking habits the average consumption was $29(0-125)$ pack-years; 17 were lifelong non-smokers. This difference in smoking habits is not significant. Smoking habits could be obtained for both individuals in 59 pairs. In 36 of the pairs both the exposed and control were smokers, in six pairs both were non-smokers, and in eight pairs only the exposed, and in nine only the control had ever smoked.

\section{INDIVIDUAL DOSE ESTIMATES}

For each case, data on various job assignments were collected from the company personnel records and were complemented with information from a former foreman in the factory. The cumulative dose was calculated as level of exposure $x$ duration of each job held, and expressed as fibre-years $(\mathrm{f} / \mathrm{ml} \times$ years; $\mathrm{f}-\mathrm{y} / \mathrm{ml}$ ). In 14 workers, all with short term employment for whom no details concerning job assignments were available, the mean level of exposure of all jobs for the appropriate period was assumed.

The exposed workers had been employed on average for $15(0.25-47)$ years. The average latency from first exposure to death was $26(1-63)$ years. The average cumulative asbestos dose was $26(0 \cdot 2-230) \mathrm{f}-\mathrm{y} / \mathrm{ml}$. The average intensity of exposure (cumulative dose divided by total duration of exposure) was 1.8 $(0 \cdot 1-7 \cdot 5) \mathrm{f} / \mathrm{ml}$.

\section{HISTOLOGICAL EXAMINATION}

All slides were examined without knowledge of identity, exposure, disease, or findings at necropsy.

Only "asbestos bodies" with an optically transparent core and a yellow brown iron protein coat were counted. In the text they are referred to as "ferruginous bodies," avoiding the term asbestos bodies as the nature of the core was not analysed.

Ferruginous bodies were studied in $25 \mu$ unstained sections (about $1 \mathrm{~cm}^{2}$ ) and scored $0-3$, where score 0 refers to the absence of ferruginous bodies, score 1 denotes about 1-15, score 2 denotes 15-75, and score 3 denotes more than 75 ferruginous bodies.

To study the degree of fibrosis all sections were stained with haematoxylin and eosin, Van Giesonelastica, and the Gordon Sweet reticulum stain. The severity of the fibrosis was graded ${ }^{11}: 0=$ None; $1=$ the lesions consist of a slight focal fibrosis around respiratory bronchioles; $2=$ the lesions are confined? to respiratory bronchioles of scattered acini. Fibrosis extends to alveolar ducts and atria as well as to the? wall of adjacent air sacs; 3 = further increase ando condensation of the peribronciolar fibrosis with early $\underline{\underline{\underline{n}}}$ widespread interstitial fibrosis; and, $4=$ few alveolif are recognisable in the widespread diffuse fibrosis: $\mathbb{\Omega}$ bronchioli are distorted. The different degrees of fibrosis are illustrated in the figure.

\section{STATISTICAL METHODS}

The material was primarily analysed taking theo matching into account. That is, the unit of analysisod was each exposed worker and control pair. The Wil-3 coxon matched pair signed rank test was thus used to test for the differences in levels of ferruginous bodiesoo and fibrosis between the exposed and control sub-c jects. To test for possible dose-response associations with asbestos exposure a chi-square test for trendo applied to the proportion of pairs in which the exposed worker had more ferruginous bodies or more severe fibrosis. In dissolved pairs chi-square test, chi은 square test for trend, and the non-parametric rank $\stackrel{\text { s }}{+}$ correlation coefficient, and Kendall's tau were used toco test associations. "Statistically significant" refers to $\mathrm{p}<0.05$. All $\mathrm{p}$ values are two tailed, unless otherwise stated.

\section{Results}

\section{CAUSES OF DEATH}

In three exposed workers pulmonary fibrosis was stated as cause of death. There was no such diagnosis $\exists$ among the controls, among whom were seven cases with obstructive pulmonary disease.

When the final necropsy report, which may be con-o sidered as the best evidence available, was used, five 3 deaths from pulmonary fibrosis among the exposedo subjects were found and none among the controls: Pneumonia and pulmonary embolism were mores common causes of death among the exposed workers than the controls. In the final necropsy reports theseo diagnoses are stated less frequently than on the death certificate, due to the recognition of a major under-oㅡㅡ. lying disease (table 2). Further, there were microscopic signs of pneumonia in 42 of the exposed subjects versus 36 of the controls (not in table). The 0 latter difference is not significant.

As cases with tumour tissue in the pulmonaryo microscopic slides were excluded, no general conclusions can be drawn as to the frequency of malignancies in the material. According to the beston available evidence, however, 25 exposed workers and 28 controls had tumours at other sites than are showno in the slides (table 2). 


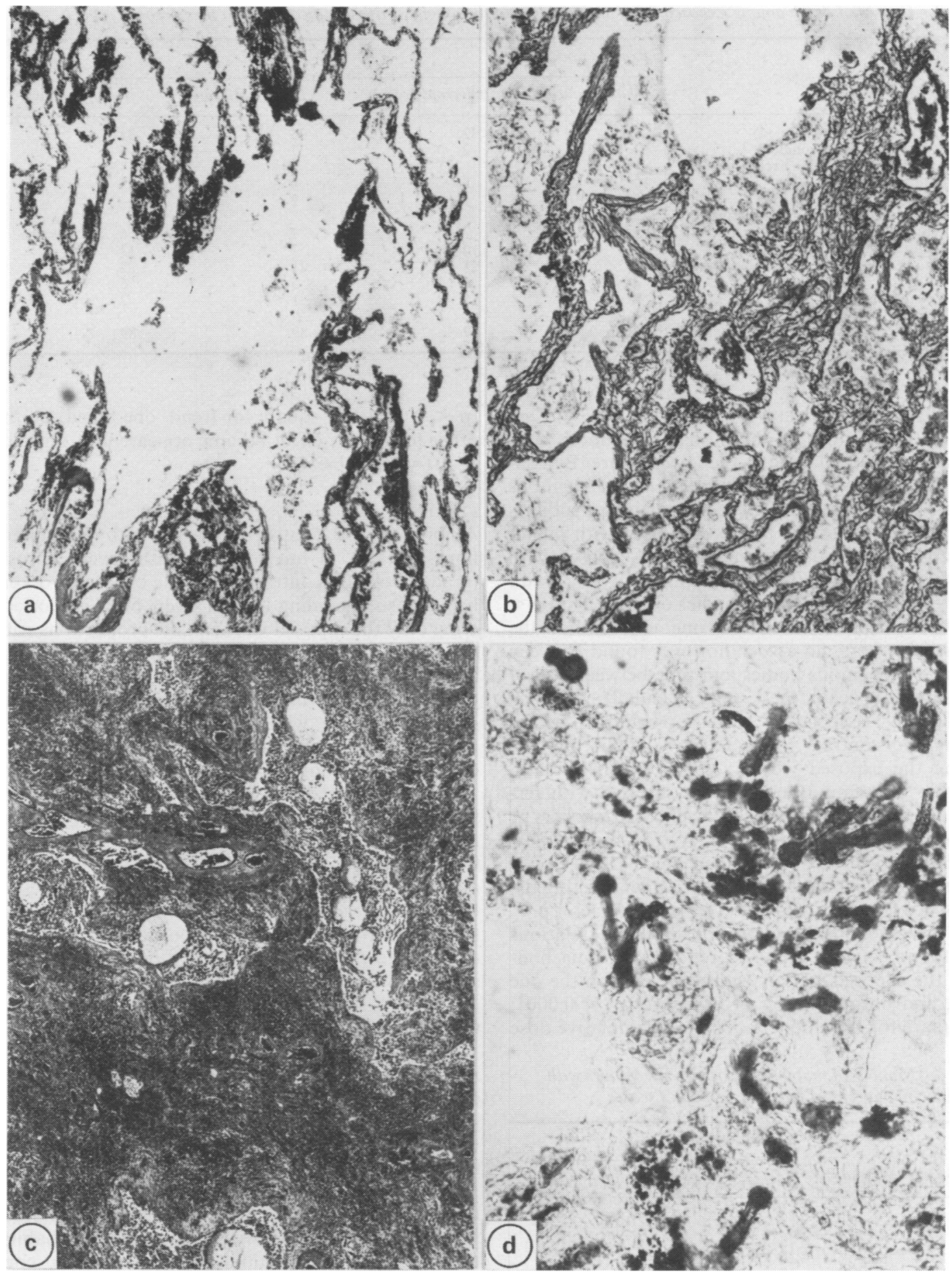

(a) Lesion grade 2. Slight extension of fibrosis to acini. Gordon Sweet reticulum stain $\times 60$. (b) Lesion grade 3. Early widespread interstitial fibrosis. Gordon Sweet reticulum stain $\times 80$. (c) Lesion grade 4. Massive fibrosis with architecture of lung totally destroyed. Gordon Sweet reticulum stain $\times 20$. (d) Ferruginous bodies in a dense fibrotic area. There is much carbon pigment in lesion. This corresponds to ferruginous bodies grade 3. $25 \mu$ unstained section $\times 300$. 
Table 2 Causes of death among exposed subjects according to the official death certificate and to the necropsy report

\begin{tabular}{|c|c|c|c|c|}
\hline \multirow[b]{2}{*}{ Causes of death } & \multicolumn{2}{|l|}{ Exposed workers } & \multicolumn{2}{|l|}{ Controls } \\
\hline & Death certificate & Necropsy report & Death certificate & Necropsy report \\
\hline Vascular disease (stroke included) & 35 & 32 & 35 & 33 \\
\hline \multirow{2}{*}{\multicolumn{5}{|c|}{ Pulmonary disease (tumours excluded): }} \\
\hline & & & & \\
\hline Pneumonia & 10 & 6 & 4 & 3 \\
\hline Pulmonary embolism & 5 & 1 & 2 & - \\
\hline \multicolumn{5}{|l|}{ Other pulmonary disease (obstructive } \\
\hline and restrictive, including cor pulmonale) & 5 & 7 & 7 & 6 \\
\hline Other diseases, except tumours & 6 & 10 & 7 & 12 \\
\hline Carcinoma & 16 & 21 & 21 & 22 \\
\hline Sarcoma & 3 & 4 & 5 & 6 \\
\hline Trauma or intoxication & 5 & 6 & 1 & 2 \\
\hline Total & 89 & 89 & 89 & 89 \\
\hline
\end{tabular}

\section{FERRUGINOUS BODIES}

Among the 89 controls, only 12 had ferruginous bodies (table 3) and all were of the lowest score. By contrast, 57 of the 89 exposed subjects had ferruginous bodies, 21 with score $2-3$. The proportion of subjects with many ferruginous bodies increased with higher asbestos dose. Two per cent of those exposed with $<10 \mathrm{f}-\mathrm{y} / \mathrm{ml}, 29 \%$ with $11-40 \mathrm{f}-\mathrm{y} / \mathrm{ml}$, and $69 \%$ with $>40 \mathrm{f}-\mathrm{y} / \mathrm{ml}$ had ferruginous bodies of grade $2-3$ ( $<<$ 0.0001 , chi-square for trend, one tailed). For the exposed workers, no association was found between levels of ferruginous bodies and time between end of exposure and death $(\mathrm{p}=0.28$; Kendall). Age was significantly associated with ferruginous bodies among the controls $(p=0.03$; Kendall) but not among the exposed workers $(p=0.17$; Kendall). Tobacco consumption was not associated with ferruginous bodies among either the exposed workers or the controls $(\mathrm{p}=0.26$ and $\mathrm{p}=0.34$ respectively; Kendall).

Ferruginous bodies were more frequent among the exposed workers in all but seven pairs (table 3; p < 0.0001; Wilcoxon). Positive dose-response relations were found between higher score for ferruginous bodies in the exposed worker within the pair on the one hand, and both duration of exposure ( $p<0.0001$; chi-square for trend, one tailed) and cumulative dose

Table 3 Number of matched exposed/control pairs with various combinations of ferruginous bodies scores

\begin{tabular}{lrrrrr}
\hline \multicolumn{5}{l}{ Control's score } \\
\cline { 2 - 6 } Exposed worker's score & 0 & 1 & 2 & 3 & Total \\
\hline 0 & 25 & 7 & 0 & 0 & 32 \\
1 & 32 & 4 & 0 & 0 & 36 \\
2 & 18 & 0 & 0 & 0 & 18 \\
3 & 2 & 1 & 0 & 0 & 3 \\
Total & 77 & 12 & 0 & 0 & 89 \\
\hline
\end{tabular}

(p $<0.0001$; chi-square for trend, one tailed) on the or other hand. The effect became appearent at doses of $1-10 \mathrm{f}-\mathrm{y} / \mathrm{ml}$ (table 4).

\section{FIBROSIS}

Among the 89 controls were 56 with pulmonary fibrosis (table 5) but only six with severe fibrosis (grades 3-4). By contrast, 68 of the exposed workers $\vec{\oplus}$ had fibrosis, including 16 with severe fibrosis. Consid- $\stackrel{\infty}{v}$ ering only the exposed workers, the proportions with fibrosis of grade 2 or worse were $40 \%$ with a cumulative dose $<10 \mathrm{f}-\mathrm{y} / \mathrm{ml}, 35 \%$ with $11-40 \mathrm{f}-\mathrm{y} / \mathrm{ml}$, and $62 \%$ with $>40 \mathrm{f}-\mathrm{y} / \mathrm{ml}$ ( $\mathrm{p}=0.07$, chi-square for trend, one tailed). Age was significantly associated with $\frac{\varnothing}{}$ fibrosis among the exposed workers $(p=0.04$; Ken- $\stackrel{\varrho}{\Rightarrow}$ dall) but not among the controls $(p=0.28$; Kendall).

In a paired analysis, considering higher degree of fibrosis for the exposed worker within the pair, fibrosis was more pronounced among the exposed workers (table 5; $\mathrm{p}=0.005$; Wilcoxon). An association with cumulative asbestos dose was suggested $\exists$ but did not reach significance (table $6 ; p=0.07$; chisquare for trend, one tailed). Duration of exposure did not show a significant association $(p=0.30$; chisquare for trend, one tailed).

\section{RELATION BETWEEN FIBROSIS AND \\ FERRUGINOUS BODIES}

Among the exposed workers there was a strong association between ferruginous body score and fibrosis grade (table 7; $p=0.005 ;$ Kendall). A similar relation 0 was also found among the controls $(p=0.034 ; \mathrm{Ken}-\mathrm{N}$ dall).

RELATION BETWEEN SMOKING AND FIBROSIS Among the 67 controls with known smoking habits, $\stackrel{\oplus}{+}$ there was an association between tobacco con- $\square$ sumption and fibrosis grade (table 8; $\mathrm{p}=0.048$; Ken-음 dall, one tailed). Such an association was not evident 
Table 4 Number of matched exposed/control pairs in which the exposed worker has a lower/equal/higher (with per cent) score on ferruginous bodies as compared with his/her control, for various levels of cumulative asbestos dose, expressed as fibre-years $(f-y / m l)$

\begin{tabular}{llllr}
\hline & & \multicolumn{2}{c}{ Score for exposed subject compared with score for matched control } \\
\cline { 3 - 5 } Asbestos dose of exposed worker $(f-y / m l)$ & Total & Lower & Equal & Higher \\
\hline$<1$ & 11 & 3 & 6 & $2(18 \%)$ \\
$1-10$ & 31 & 4 & 12 & $15(48 \%)$ \\
$11-20$ & 16 & 0 & 2 & $7(63 \%)$ \\
$21-30$ & 9 & 0 & 2 & $4(76 \%)$ \\
$31-40$ & 6 & 0 & 1 & $15(94 \%)$ \\
$>40$ & 16 & 0 & 29 & $53(60 \%)$ \\
Total & 89 & 7 & & \\
\hline
\end{tabular}

among the exposed workers $(p=0 \cdot 35$; Kendall, one tailed). When exposed workers with and without known smoking habits were compared, the fibrosis grade did not differ significantly $(p=0.68$; chisquare). The same result was found for the controls $(\mathrm{p}=0 \cdot 59 ;$ chi-square $)$.

\section{Discussion}

The necropsy rate in the cohort of asbestos cement workers from which the exposed workers originated was $60 \%$, the corresponding figure for the general adult male population in the area being $54 \%$. The necropsy rate was thus not appreciably raised among the asbestos cement workers and we have no reason to believe that they have been treated in any particular way as regards necropsy.

Although new slides were prepared for all cases, the technical quality of the tissue was sometimes low. In some cases there was autolysis, haemorrhage, or infarction. In addition, we usually do not know from which lobe of the lung the sample was taken, although we have reason to believe that most of the material was from the lower lobes. This may be important, as particle deposition as well as fibrosis is not uniform in the lung. ${ }^{12}$

Effects were seen at low cumulative asbestos doses. It is thus important to ensure that we do not system-

Table 5 Number of matched exposed/control pairs with various combinations of fibrosis grades

\begin{tabular}{lrrrrrr}
\hline & \multicolumn{9}{c}{ Control's grade } & \\
\cline { 2 - 6 } Exposed worker's grade & 0 & 1 & 2 & 3 & 4 & Total \\
\hline 0 & 12 & 7 & 2 & 0 & 0 & 21 \\
1 & 11 & 10 & 9 & 0 & 0 & 30 \\
2 & 7 & 5 & 6 & 4 & 0 & 22 \\
3 & 2 & 4 & 4 & 0 & 1 & 11 \\
4 & 1 & 3 & 0 & 0 & 1 & 5 \\
Total & 33 & 29 & 21 & 4 & 2 & 89 \\
\hline
\end{tabular}

atically underestimate the levels of exposure. The estimation of early exposure included a conversion of workroom measurements from mppcf to $\mathrm{f} / \mathrm{ml}$, which is difficult. ${ }^{13}$ We estimate the calculations of concentrations to be accurate within a factor of two. The dust monitoring data from the 1970s are in good agreement with the levels given in several other investigations. ${ }^{14-17}$ We estimate the dust concentrations before the 1970s for most jobs to have been two to three times higher, and for the most dusty jobs, five to six times higher. The dust monitoring measurements with the impinger method, performed in 1957 , although of short duration, are in good accordance with those from another Swedish asbestos cement industry, ${ }^{15}$ and with some other data, ${ }^{18}$ but lower than some reports. ${ }^{1517}$ The variations may be due to a real difference between factories. Also, if the duration of specific tasks during the workday has not been accounted for in the various studies, as we did, individual dose calculations might be overestimated.

Membrane filter techniques for estimation of air levels of asbestos fibres have changed during the years. Our data are based on the original methods and do not represent present recommendations for filter preparation and rules for fibre counting, which would give higher fibre counts. ${ }^{19}$

Information about the different work tasks used in the calculation of the individual cumulated dose was incomplete in some subjects. This tends to reduce the accuracy of the individual dose calculations, thus obscuring possible dose-response relations.

\section{FERRUGINOUS BODIES}

In this study a dose-response association between asbestos cement exposure, expressed as duration and cumulative dose, and ferruginous bodies score, was evident. A survey of ferruginous bodies with the light microscope (LM) in unstained undigested sections is a rough method for quantitative estimation of the content of asbestos fibres in the lungs. As to digestion, it has recently been shown that there is good correlation between ferruginous body count on undigested iron 
Table 6 Number of matched exposed/control pairs, in which the exposed worker has a lower/equal/higher (with per cent) degree of fibrosis compared with his/her control, for various levels of cumulative asbestos dose, expressed as fibre-years $(f-y / m l)$

\begin{tabular}{|c|c|c|c|c|}
\hline \multirow[b]{2}{*}{ Asbestos dose of exposed worker $(f-y / m l)$} & \multirow[b]{2}{*}{ Total } & \multicolumn{3}{|c|}{ Grade for exposed subject compared with grade for matched control } \\
\hline & & Lower & Equal & Higher \\
\hline $\begin{array}{l}<1 \\
1-10 \\
11-20 \\
21-30 \\
31-40 \\
>40\end{array}$ & $\begin{array}{r}11 \\
31 \\
16 \\
9 \\
6 \\
16\end{array}$ & $\begin{array}{l}4 \\
9 \\
7 \\
1 \\
0 \\
2\end{array}$ & $\begin{array}{r}4 \\
10 \\
4 \\
2 \\
3 \\
6\end{array}$ & $\begin{array}{r}3(27 \%) \\
12(39 \%) \\
5(31 \%) \\
6(67 \%) \\
3(50 \%) \\
8(50 \%)\end{array}$ \\
\hline Total & 89 & 23 & 29 & $37(42 \%)$ \\
\hline
\end{tabular}

stained sections and with digestive techniques. ${ }^{20}$ Also, ferruginous body counts with LM and scanning electron microscopy (EM) are well correlated in digested lung dissue. ${ }^{10}$ Reliable measurements of fibre dust burden in lung tissue can, however, be obtained only with EM techniques. ${ }^{21}$ Fibre counting and classification with transmission EM is now in progress on our specimens.

A quantitative association between asbestos exposure and ferruginous bodies has been shown in animals ${ }^{22}$ but, to our knowledge, not in man. Several studies have shown, however, that asbestos workers generally have more ferruginous bodies than other workers, who in their turn have more ferruginous bodies than a general adult population. ${ }^{23}$

Asbestos fibres, especially chrysotile, ${ }^{23}$ disappear from the lung with time. The exposed workers had been out of exposure for varying and often long periods before death. If ferruginous bodies disintegrate with time dose-response associations would be affected. The time passed since the end of exposure, however, was not associated with a diminishing score of ferruginous bodies. A probable explanation is that ferruginous bodies are formed mainly from amphibole fibres, which are relatively stable in the lung.
This is in agreement with findings in a general population, ${ }^{23}$ from workers exposed to different types of asbestos fibres, ${ }^{24}$ and in individuals with asbestos associated diseases. ${ }^{10}$

Among the controls, $13 \%$ had ferruginous bodies, which is less than reported in the general population living in the city of Malmö, where ferruginous bodies were found in $44 \%$ of the necropsies. ${ }^{25}$ Malmö is a nearby, relatively large city with a high proportion of manual workers, including workers from a large shipyard. Our material originated mainly from a smaller town, without a shipyard, and from its rural surroundings. Earlier investigations have shown that urban dwellers have more ferruginous bodies than rural dwellers. ${ }^{2627}$ The Malmö material also showed a higher frequency of ferruginous bodies than most comparable urban materials. ${ }^{26-30}$ Thus we find the lower figure in our study reasonable.

Age was associated with ferruginous bodies among controls. This may be due to an accumulation with time or to a higher exposure in the general population in earlier decades.

\section{PULMONARY FIBROSIS}

This finding was more common and more pro-

Table 7 Number of exposed subjects and controls classified by grade of fibrosis and ferruginous bodies score

\begin{tabular}{|c|c|c|c|c|c|c|}
\hline \multirow[b]{2}{*}{ Fibrosis grade } & \multirow[b]{2}{*}{ Exposure group } & \multicolumn{4}{|c|}{ Ferruginous bodies score } & \multirow[b]{2}{*}{ All } \\
\hline & & 0 & $l$ & 2 & 3 & \\
\hline 0 & $\begin{array}{l}\text { Exposed subject } \\
\text { Control }\end{array}$ & $\begin{array}{l}11 \\
32\end{array}$ & 10 & $\mathbf{0}$ & $\stackrel{0}{0}$ & $\begin{array}{l}21 \\
33\end{array}$ \\
\hline \multirow[t]{2}{*}{1} & Exposed subject & 10 & 16 & 3 & 1 & 30 \\
\hline & Control & 24 & 5 & 0 & 0 & 29 \\
\hline \multirow[t]{2}{*}{2} & Exposed subject & 5 & 5 & 11 & 1 & 22 \\
\hline & Control & 16 & 5 & 0 & 0 & 21 \\
\hline \multirow[t]{2}{*}{3} & Exposed subject & 4 & 4 & 3 & $\mathbf{0}$ & 11 \\
\hline & Control & 3 & 1 & 0 & 0 & 4 \\
\hline \multirow[t]{2}{*}{4} & Exposed subject & 2 & $\begin{array}{l}1 \\
0\end{array}$ & 1 & 1 & $\begin{array}{l}5 \\
2\end{array}$ \\
\hline & Control & 2 & 0 & 0 & 0 & 2 \\
\hline Total & $\begin{array}{l}\text { Exposed } \\
\text { Control }\end{array}$ & $\begin{array}{l}32 \\
77\end{array}$ & $\begin{array}{l}36 \\
12\end{array}$ & $\begin{array}{r}18 \\
0\end{array}$ & $\begin{array}{l}3 \\
0\end{array}$ & $\begin{array}{l}89 \\
89\end{array}$ \\
\hline
\end{tabular}


Table 8 Number of exposed subjects and controls classified by grade of fibrosis and smoking habits

\begin{tabular}{|c|c|c|c|c|c|c|c|}
\hline \multirow{2}{*}{$\begin{array}{l}\text { Smoking habits } \\
\text { (pack-years) }\end{array}$} & \multirow[b]{2}{*}{ Exposure group } & \multicolumn{5}{|c|}{ Fibrosis grade } & \multirow[b]{2}{*}{ Al } \\
\hline & & 0 & $I$ & 2 & 3 & 4 & \\
\hline \multirow[t]{2}{*}{0} & Exposed & 5 & 5 & 4 & 3 & 2 & 19 \\
\hline & Control & 8 & 5 & 3 & 0 & 1 & 17 \\
\hline \multirow[t]{2}{*}{$1-20$} & Exposed & 7 & 9 & 5 & 4 & 0 & 25 \\
\hline & Control & 8 & 7 & 2 & 0 & 0 & 17 \\
\hline \multirow[t]{2}{*}{$21-40$} & Exposed & 4 & 8 & 5 & 3 & 2 & 22 \\
\hline & Control & 5 & 3 & 4 & 1 & 1 & 14 \\
\hline \multirow[t]{2}{*}{$>40$} & Exposed & 3 & 4 & 6 & 1 & 1 & 15 \\
\hline & Control & 4 & 8 & 4 & 2 & 0 & 18 \\
\hline Unknown & Exposed & $\begin{array}{l}2 \\
8\end{array}$ & $\begin{array}{l}4 \\
6\end{array}$ & 2 & 0 & $\begin{array}{l}0 \\
0\end{array}$ & $\begin{array}{r}8 \\
23\end{array}$ \\
\hline Total & Exposed & 21 & 30 & 22 & 11 & 5 & 89 \\
\hline & Control & 33 & 29 & 21 & 4 & 2 & 89 \\
\hline
\end{tabular}

nounced in exposed workers than in controls and also an association between cumulative dose and degree of fibrosis was suggested, though not statistically significant.

The grading of microscopic fibrosis has some degree of uncertainty. A lack of precision, however, should rather dim than exaggerate any existing association with exposure.

The employees in the factory were exposed to Portland cement, which may contain silica. Nodular lesions in the necropsy material, however, suggesting lung fibrosis due to silicoses were not found.

The association of fibrosis with exposure was less strong than that between ferruginous bodies and exposure. This is reasonable, as the formation of ferruginous bodies around inhaled fibres is a rather specific reaction after exposure to asbestos, whereas lung fibrosis is a non-specific reaction caused by various noxious stimuli and may also be more host dependent. Our data is in accordance with a recent study of selected patients with varying occupational exposure to asbestos, in whom the histological grade of fibrosis was shown to be related to uncoated fibre count and total fibre count, using tissue digestive techniques and scanning EM. ${ }^{10}$

Living workers from the present asbestos cement factory, at examination by $x$ ray computed tomography (unpublished observations) and extensive lung function tests (unpublished observations), display signs of increased lung density and reduced compliance. These findings also support a fibrosing effect of asbestos cement.

In previous dose-response studies relations between exposure to asbestos cement and asbestos related pulmonary disease have been expressed as clinical asbestosis, ${ }^{17}$ radiological fibrosis, ${ }^{931}$ and physiological changes. ${ }^{31}$ In those studies the cumulative doses have been higher than in our workers. As the effects have usually not been separately analysed in the low dose area, it is not possible to draw any general conclu- sions from these studies concerning the possible fibrosing effects of low exposure. Also, histological evaluation is probably a more sensitive method.

An association between cigarette smoking and microscopic lung fibrosis, ${ }^{5}$ and increased lung density in $x$ ray computed tomography, ${ }^{32}$ has been noted. This is in agreement with our findings among the controls.

We found no association between smoking and either ferruginous bodies or fibrosis in exposed workers. This is in contrast with reports that, among insulators cigarette smokers had an increased risk of dying from asbestosis ${ }^{21}$ and an association between histological grade of fibrosis and smoking in selected asbestos exposed patients. ${ }^{10}$ Also, studies of lung function and $x$ ray changes have indicated that smoking accentuates the fibrotic effect of asbestos, ${ }^{68}$ including asbestos cement. ${ }^{93-35}$ These findings, however, have been questioned. ${ }^{36}$ The lack of association between smoking and fibrosis among the exposed workers in the present study does not, however, exclude that a small effect of smoking, similar to that among the controls, may be hidden by a stronger fibrosing effect of asbestos exposure, but a strong interaction between smoking and asbestos exposure is unlikely.

We found a strong association between ferruginous bodies and fibrosis in the exposed subjects and in the controls. This is in agreement with earlier studies of individuals with occupational exposure. ${ }^{3738}$ The present workers were mainly exposed to chrysotile but there was also a small exposure to amphiboles. Thus conclusions about the relative fibrogenic effects of different fibre types cannot be drawn from this study. The finding of an association between ferruginous bodies and fibrosis among the controls may be explained by the presence of asbestos exposure among some of the controls, construction workers, for example.

Pulmonary fibrosis was the cause of death accord- 
ing to the death certificate in only three of the exposed workers. The clinical significance of the much more prevalent finding of microscopical fibrosis is unclear. It is, however, quite likely that some of the individuals with a fibrosis grade of 3-4 were respiratory disabled to some degree.

It is reasonable that the threshold limit value for asbestos should be low enough to ensure that histological pulmonary fibrosis is avoided.

The investigation has received a grant from the Swedish Work Environment Fund (ASF 79/288). We thank Dr Robert Cameron, Ms Annika Forsberg, Ms Carina Johansson, Ms Gun Kungberg, Ms Gertrud Lennartsson, and the late Mr Gunnar Nilsson for valuable help.

Requests for reprints to: Leif Johansson, Department of Pathology, University Hospital, S-221 85 Lund, Sweden.

\section{References}

1 Merewether ERA, Price CV. Report on the effects of asbestos dust on the lungs and dust suppression in the asbestos industry. London: HMSO, 1930.

2 Dreessen WC, Dallavalle JM, Edwards M, Miller JW. A study of asbestosis in the asbestos textile industry. Public Health Bull 1938;241:68-9.

3 Becklake MR. Asbestos-related diseases of the lungs and pleura. Current clinical issues. Am Rev Respir Dis 1982;126:187-94.

4 Baeten J, Helsen J, Deruyttere A. Nature, structure, and properties of asbestos cement dust. Br J Ind Med 1980;37:33-41.

5 Auerbach O, Garfinkel L, Hammond EC. Relation of smoking and age to findings in lung parenchyma: a microscopic study. Chest 1974;65:29-35.

6 Weiss W. Cigarette smoking, asbestos and pulmonary fibrosis. Am Rev Respir Dis 1971;104:223-7.

7 Hammond EC, Selikoff IJ, Seidman H. Asbestos exposure, cigarette smoking and death rates. Ann NY Acad Sci 1979; 330:473-90.

8 McMillan GHG, Pethybridge RJ, Sheers G. Effect of smoking on attack rates of pulmonary and pleural lesions related to exposure to asbestos dust. Br J Ind Med 1980;37:268-72.

9 Finkelstein MM, Vingilis JJ. Radiographic abnormalities among asbestos-cement workers. Am Rev Respir Dis 1984;129:17-22.

10 Roggli VL, Pratt PC, Brody AR. Asbestos content of lung tissue in asbestos associated diseases: a study of 110 cases. $\mathrm{Br} J$ Ind Med 1986;43:18-28.

11 Hinson RFV, Otto H, Webster I, Rossiter CE. Criteria for the diagnosis and grading of asbestosis. In: Bogovski P, Gilson JC, Timbrell V, Wagner JC, eds. Biological effects of asbestos. Lyon: International Agency for Research on Cancer, 1973: 54-8.

12 Churg A, Wood P. Observations on the distribution of asbestos fibers in human lungs. Environ Res 1983;31:374-80.

13 Gibbs GW, Lachance M. Dust-fiber relationships in the Quebec chrysotile industry. Arch Environ Health 1974;28:69-71.

14 Hammad YY, Diem J, Weill H. Evaluation of dust exposure in asbestos cement manufacturing operations. Am Ind Hyg Ass J 1979;40:490-5.

15 Ohlson CG, Hogstedt C. Lung cancer among asbestos cement workers. A Swedish cohort study and a review. $\mathrm{Br} J$ Ind Med
1985;42:397-402.

16 Thomas HF, Benjamin IT, Elwood PC, Sweetnam PM. Furthe follow-up study of workers from an asbestos cement factory? Br J Ind Med 1982;39:273-6.

17 Finkelstein MM. Asbestosis in long-term employees of are Ontario asbestos-cement factory. Am Rev Respir Dis 1982. 125:496-501.

18 Banerji DP. Asbestosis in an asbestos cement factory. Indian Journal of Industrial Medicine 1968;14:157-66.

19 Simpson WJ. What should be the rationale for regulations of asbestos? In: Proceedings of the world symposium on asbestos Montreal 1982. Montreal: Canadian Asbestos Informations Centre, 1982:492-7.

20 Roggli VL, Pratt PC. Numbers of asbestos bodies on iron-stained tissue sections in relation to asbestos bodies counts in lung tissue digests. Hum Pathol 1983;14:355-61.

21 Selikoff IJ. Lee DHK. Asbestos and disease. New York: Academi Press, 1978.

22 Wehner AP, Dagle GE, Cannon WC. Development of an animaA model, techniques, and an exposure system to study the effects of asbestos cement dust inhalation. Environ Res 1978;16 393-407.

23 Churg AM, Warnock ML. Asbestos and other ferruginous bode ies. Am J Pathol 1981;102:447-56.

24 Pooley FD. Asbestos bodies, their formation, composition an $\$$ character. Environ Res 1972;5:363-79.

25 Hägerstrand I, Seifert B. Asbestos bodies and pleural plaques iß human lungs at necropsy. Acta Pathol Microbiol Scant 1973;81:457-60.

26 Ashcroft T. Asbestos bodies in routine necropsies on Tyneside: pathological and social study. $\mathrm{Br}$ Med $J$ 1968;i:614-8.

27 Betta PG. Corpuscoli dell'asbesto nella popolazione general 8 della provincia di Alessandria. Med Lav 1982;1:58-64.

28 Roberts GH. Asbestos bodies in lungs at necropsy. J Clin Pathat 1967;20:570-3.

29 Um Chang-Hyun. Study of the secular trend in asbestos bodies is lungs in London 1936-66. Br Med J 1971;ii:248-52.

30 Steele RH, Thomson RJ. Asbestos bodies in the lung Southampton (UK) and Wellington (New Zealand). $\mathrm{Br}$ 只 Ind Med 1982;39:349-54.

31 Weill H, Ziskind MM, Waggenspack C, Rossiter CE. Lung func tion consequences of dust exposure in asbestos cement manu facturing plants. Arch Environ Health 1975;30:88-97.

32 Wollmer P, Albrechtsson V, Brauer K, Eriksson L, Jonsson B? Tylen U. Measurement of lung density by means of $x$ ray com puted tomography: relation to lung mechanics in normal sub jects. Chest (in press).

33 Weiss W, Theodos P. Pleuropulmonary disease among asbestos workers in relation to smoking and type of exposure. $J$ Occion Med 1978;20:341-5.

34 Jones RN, Diem JE, Glindmeyer H, Weill H, Gilson JC. Progression of asbestos radiographic abnormalities relationships to estimates of dust exposure and annual declin? in lung function. In: Wagner JC, ed. Biological effects of mir? eral fibres. Vol 2. Lyon: International Agency for Research on Cancer, 1980:537-43. (Sci publ No 30.).

35 Finkelstein MM. A study of dose-response relationship for asbes: tos associated disease. Br J Ind Med 1985;42:319-25.

36 Kilburn KH. Cigarette smoking does not produce or enhance the radiologic appearance of pulmonary fibrosis. $\mathrm{Am} \mathrm{J}$ Ind Mend 1981;2:305-8.

37 Ashcroft T, Heppleston AG. The optical and electron microw scopic determination of pulmonary asbestos fibre concen tration and its relation to the human pathological reaction. Clin Pathol 1973;26:224-34.

38 Sebastien P, Fondimare A, Bignon J, Monchaux G, Desbordes Bonnaud G. Topographic distribution of asbestos fibers in human lung in relation to occupational and non-occupationat exposure. In: Walton WH, McGovern B, eds. Inhaled particles and vapours. Vol IV. New York: Pergamon Press, 1977:435-4历D 